Agricultural Research Council : Studentships and Fellowships

A BOOKLET issued by the Agricultural Research Council gives details of the postgraduate studentships and research fellowships offered by the Council in 1960 (Pp. 16. London: Agricultural Research Council, 1960). Besides 30 studentships tenable for one to three years, three junior agricultural research fellow. ships tenable for three years, valued at $£ 700-£ 1,000$ per annum, are offered and two veterinary research fellowships tenable for three years, rising from $£ 900$ to $f 1,000$. The studentships, which cover training in agricultural engineering, dairy engineering and statistics, and a limited number of veterinary training grants for four years duration to enable science graduates to read for a veterinary qualification, are for $£ 340-£ 520$ per annum, tax free, together with educational fees. The booklet also outlines the scope of agricultural research and the openings available in agricultural research and advisory work. Of the 407 awards since 1932, 43 are still current; 153 holders have entered on careers in agricultural research or advisory services at research institutes, etc., 88 have taken up similar university appointments and 45 overseas appointments.

\section{Research Corporation of the United States}

THE Research Corporation was founded by Frederick Gardner Cottrell, scientist, teacher and inventor, in 1912. Cottrell gave the proceeds from his inventions in the electrostatic precipitation of gas particles as an endowment to make grants for scientific research. Since 1912 more than 2,500 scientists have been aided by grants to institutions in the United States and in other countries totalling more than 13 million dollars. During 1959 the Foundation distributed approximately 1.2 million dollars for 383 grants. It is announced that grants ranging from 1,100 dollars to 12,000 dollars have already been awarded to forty-three United States and foreign colleges for the current year. So far forty-eight grants have been awarded for research : in chemistry (34), physics (9), astronomy (2), and the biological sciences (3).

\section{The Swinburne Award}

THe Council of the Plastics Institute announces that the Swinburne Award, instituted in 1959 and consisting of a gold medal, a certificate and a sum of money, will now be an international award. The award will be made to persons, whether members or non-members of the Institute, who shall have made an outstanding contribution to the science or technology of plastics or of plastics engineering.

\section{Asia Foundation Grants}

The American Geographical Society announces that it has received a grant of 2,500 dollars from the Asia Foundation to aid Asian libraries and Asian scholars temporarily in the United States. The grant will be used to provide selected libraries with the society's journal, The Geographical Review. In addition, small stipends, ranging up to 300 dollars, will be offered to students and scholars currently in the United States, to enable them to do research at the society. Applicants must be at least at the graduate level and may come from any Asian country from Afghanistan eastward, except for Australia, Now Zealand, and territories of the South Pacific. Further information can be obtained from Dr. Charles B. Hitchcock, director of the American Geographical Society, 156th Street and Broadway, New York City.

\section{Competition for Science Teachers}

THe journal Teaching Science has organized a competition for science teachers. Entries are invited for articles concerning a new technique or content in classroom work, the development of special interest in the pupil, the fostering of the outstanding child or the development of the backward child, or the encouragement of group activities in the classroom or outside. The fostering of special relations with industry or the local museum or library, or the use of new materials, is included. $£ 100$ in prizes are offered to cover two groups of entries, namely, an ' $S$ ' group which includes all types of Secondary Schools up to O-level G.C.E., and 'P', Primary Schools. In each group there will be four awards totalling $£ 50$. The awards will be made by an independent committee. The closing date for entries is May 31. Further information can be obtained from T.S.T.S., Teaching Science, 5 Great James Street, London, W.C.1.

\section{Australian Irradiation Conference}

The Australian Atomic Energy Commission is holding a conference on the Technological Use of Radiation at the University of New South Wales during May 23-25. The object of the conference is to review recent developments and to stimulate research and interest in the technological applications of radiation. It is intended that the conference should cover the following topics: food preservation; sterilization of medical supplies; sterilization of industrial raw materials; uses in the chemical industry (polymerization, modification of polymers, promotion of chemical reactions, ete.); insect pest control ; genetic applications. Further information can be obtained from the Secretary of the Irradiation Conference, Australian Atomic Energy Commission Research Establishment, Private Mail Bag, Sutherland, Now South Wales, Australia.

University News :

Leeds

The annual report of the Librarian, University of Leeds, for the session 1958-59, records accessions during the year of 20,213 volumes, 2,623 pamphlets and 29,721 periodical parts, bringing the total holdings to 639,249 books, of which 439,987 are in the Brotherton Library, 35,879 in the Medical Library and 39,890 in the Agricultural Library (pp. 12. Leeds: The Brotherton Library, The University, 1959). Inter-library loans comprised 1,496 books borrowed and 3,163 lent. The third stage of the mezzanine floor construction, providing shelving for 70,000 volumes and 44 study rooms, was completed for the beginning of the 1958-59 session, and the seating eapacity of the Brotherton Library is now about 700 with some 275 further seats in sectional libraries. Other accommodation, however, is also required, such as a new co-ordination of catalogue, reference books and counter on a much larger scale and entirely outside the Reading Room. A fall of 4 per cent in cataloguing output is attributed to staff changes and to increasing claims on cataloguers' time.

Oxford

Grants are announced from the following bodies: Department of Scientific and Industrial Research, 